Çukurova Üniversitesi Mühendislik Fakültesi Dergisi, 36(3), ss. 669-679, Eylül 2021

Çukurova University Journal of the Faculty of Engineering, 36(3), pp. 669-679, September 2021

\title{
The Effect of Using Different Refrigerants on System Performance in Two-Stage Organic Rankine Cycle
}

\author{
Ahmet KAPLAN"1, Arif OZBEK ${ }^{2}$ \\ ${ }^{1}$ Cukurova University, Faculty of Engineering, Department of Mechanical Engineering, Adana \\ ${ }^{2}$ Cukurova University, Faculty of Ceyhan Engineering, Department of Mechanical Engineering, \\ Adana
}

Geliş tarihi: 29.06.2021 Kabul tarihi: 13.09.2021

\begin{abstract}
In this study, energy analysis of a double-stage Organic Rankine Cycle (ORC) was performed using the Engineering Equation Solver program (EES). In the first and second stages, eight different organic working fluids (R134a, R410a, RC318, R407c, R22, R23, R116, and R218) were used in pairs for certain temperature limits. Choosing a suitable refrigerant or refrigerant pair is crucial for the ORC's high thermal efficiency and net work output value. This study aims to determine the effect of working fluid on system efficiency and find out the most suitable working fluid pair. The results showed that the highest net power output and the highest thermal efficiency were obtained from the R23+R23 pair. It was also observed that the lowest net power output from the RC318+RC318 pair and the lowest thermal efficiency was obtained from the R218+R218 pair.
\end{abstract}

Keywords: Organic rankine cycle, Double stage cycle, Solar power

\section{İki Aşamalı Organik Rankine Çevriminde Farklı Soğutucu Akışkan Kullanımının Sistem Performansına Etkisi}

\section{Özet}

Bu çalışmada mühendislik denklem çözücü program (Engineering Equation Solver - EES) kullanılarak iki kademeli bir Organik Rankine Çevriminin (ORC) enerji analizi yapılmıştır. Birinci ve ikinci kademelerde sekiz farklı organik akışkan (R134a, R410a, RC318, R407c, R22, R23, R116 ve R218) çiftler halinde belirli sıcaklık limitleri arasında kullanılmıştır. ORC'nin yüksek ısıl verim ve net iş çıktısı için uygun bir soğutucu akışkan veya soğutucu akışkan çifti seçimi yapmak çok önemlidir. Bu çalışmanın amacı, çevrim akışkanının sistem verimine etkisini belirlemek ve en uygun akışkan çiftini bulmaktır. Sonuçlar, en yüksek net güç çıkışının ve en yüksek termal verimin R23+R23 çiftinden elde edildiğini göstermektedir. Ayrıca en düşük net güç çıkışının RC318+RC318 çiftinden ve en düşük termal verimin ise R218+R218 çiftinden elde edildiği gözlemlenmiştir.

Anahtar Kelimeler: Organik rankine çevrimi, İki aşamalı çevrim, Güneş enerjisi

\footnotetext{
*Sorumlu Yazar (Corresponding author): Ahmet KAPLAN, ahmttkplnn@gmail.com
} 


\section{INTRODUCTION}

Power generation from waste heat, turbine exhaust, solar and biomass energy is becoming a popular way to generate alternative energy for industry. Low heat sources can be converted to electrical energy and these can be used in an ORC system design. Basic principles of ORC, very similar to the conventional Rankine cycle. However, the main difference is the use of organic working fluid of the ORC [1]. Also, Rankine cycle requires minimum power to be competitive and high collector temperature [2]. The main problems for generating power economically with water/steam driven working cycles is that low $\left(<230{ }^{\circ} \mathrm{C}\right)$ and medium $\left(230^{\circ} \mathrm{C}-640{ }^{\circ} \mathrm{C}\right)$ temperature heat sources are not suitable [3]. Also when using water as a working fluid, many problems are encountered: during expansion need of superheating to prevent condensation, excess pressure in the evaporator, risk of erosion of turbine blades, expensive and complex turbines [4]. Various cycles such as organic Rankine, supercritical Rankine, Kalina, Goswami and triple flash cycles have been investigated for the generation of electrical energy from low temperature heat sources [5]. However, ORCs have a much simpler cycle than other cycles such as the Kalina cycle or triple flash cycles [6]. Compared to the conventional Rankine cycle ORC, they require a less complicated control system and their components are a lot cheaper [7]. In 1825 Thomas Howard developed the first ORC engines. The working fluid was alcohol or ether. In 1967, the Soviet Union's first geothermal binary ORC was developed on the Kamchatka peninsula. The capacity was $680 \mathrm{~kW}$ and the working fluid was R-12 [8]. ORC technology is a promising and proven technology that is considered an essential solution for low and medium temperatures (especially between $300-450 \quad{ }^{\circ} \mathrm{C}$ ). Lowtemperature heat is converted into useful work, which itself can be converted into electricity [9]. The advantage of ORC is that various working fluids can be used first. Second, the working fluid is mostly dry fluid. Third, the working fluid has a relatively low evaporation temperature. ORC also has disadvantages, one of which is its poor heat transfer coefficient. Second, most organic liquids are poisonous and highly flammable. Therefore, the "shell and tube" type heat exchanger is easily adopted in the ORC system [10]. Numerous researchers have extensively studied the organic Rankine Cycle, focusing mainly on system structure, working fluid, and optimization of cycle parameters [11]. The refrigerants studied found that the ORC's most suitable working fluid for small-scale solar applications was R134a [12]. A bad working fluid choice could lead to a low efficient and expensive plant [13]. That means suitable fluid should have properties of high efficiency, low specific volumes and moderate pressures in the heat exchangers, low toxicity, low cost, low Ozone Depletion Potential (ODP) and low Global Warming Potential (GWP), among others [14]. The selection of the working fluid is determined by the application and the waste heat level and plays a significant role in the use of the ORC process [15].

In this paper, energy analysis of a double-stage Organic Rankine Cycle (ORC) was performed using the Engineering Equation Solver program (EES). In the first and second stages, R134a, R410a, RC318, R407c, R22, R23, R116 and R218 organic fluids were used in pairs for certain temperature limits. In order to obtain the best thermal efficiency and network output value from ORC to find out, a suitable fluid or fluid pair has been tried to determine.

\section{2-MATERIAL AND METHOD}

\subsection{System Description}

Figure 1 shows the double stage ORC system designed. In this system, the solar collector acts as a heater. The evaporator of the first stage takes the heat from the solar collector and delivers that heat to the working fluid of the first stage. After the turbine-I, the fluid is still in the superheated gas state and this heat is used as the second-stage working fluid in a Re-evaporator. After the turbine-II, the regenerator heats the compressed liquid as a pre-heater. The water is used as a cooler at both condensers. According to ASHRAE 34 Refrigerant Safety Classification group A, all refrigerants have been determined, which means low toxicity and no flame propagation group. 
ASHRAE 34 refrigerant safety classification is shown in Table 1. The first stage's working fluid and the second stage's working fluid have been set as the same refrigerant. The effectiveness-NTU method is used to model the Evaporator and Reevaporator heat exchangers.
According to the ASHRAE standard 34, there are two classes of toxicity (A: non-toxic B: toxic.) and three groups of flammability characteristics (1: no flame propagation, 2: low flammability limit and 3: high flammability limit) [16].

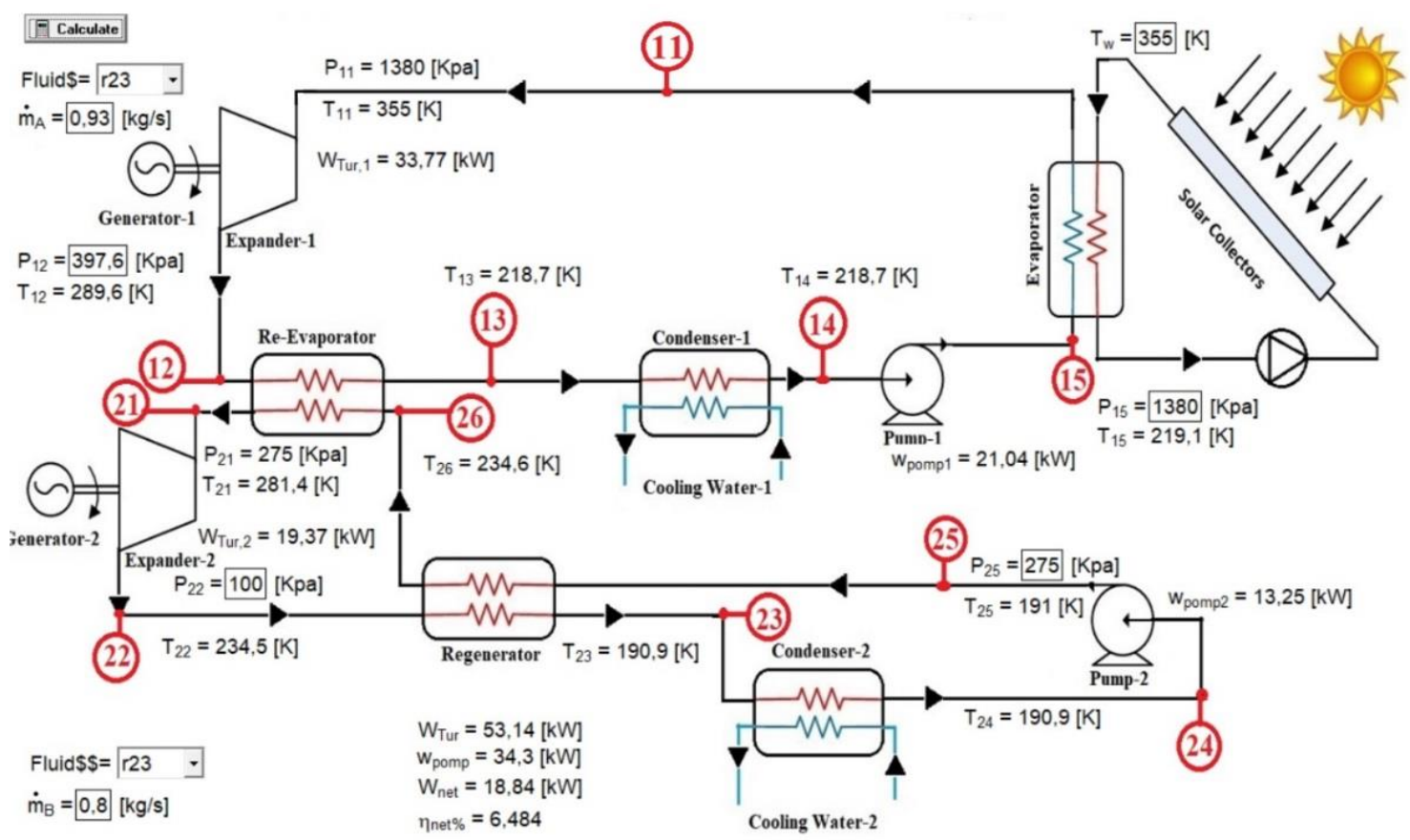

Figure 1. Schematic representation of Double Stage SORC system.

Table 1. ASHRAE 34 refrigerant safety classification

\begin{tabular}{|l|c|c|}
\hline & $\begin{array}{c}\text { Lower } \\
\text { toxicity }\end{array}$ & $\begin{array}{c}\text { Higher } \\
\text { toxicity }\end{array}$ \\
\hline Higher flammability & A3 & B3 \\
\hline Lower flammability & A2 & B2 \\
\hline No flame propagation & A1 & B1 \\
\hline
\end{tabular}

This system consists of two stages. In the first and second stages, the same fluid is used and the heat taken from the solar collector is converted into electrical energy. Solar collector can be change with all of the heat sources like geothermal energy, natural gas, waste heat, etc.. The system operates with a constant mass flow rate of $0.93 \mathrm{~kg} / \mathrm{s}$ and 0.8 $\mathrm{kg} / \mathrm{s}$ in the first and second stages, respectively. In addition, the working pressure is constant in all components and refrigerant pairs. Calculations were made between $355 \mathrm{~K}$, the lowest temperature at which all fluids can work together, and $425 \mathrm{~K}$, the highest temperature at which they can work.

Figure 2 illustrates the pressure/enthalpy diagram of the double-stage Rankine cycle designed with R23 at each stage. The points in the first stage show: $11-12$ is the turbine, $12-13$ is the reevaporator, 13-14 is a condenser, 14-15 is a pump, and $15-11$ is the evaporator where heat is gained from the solar collector. The points in the second stage show: $21-22$ is a turbine, $22-23$ is a regenerator, $23-24$ is a condenser, $24-25$ is a pump, and 25-21 is an evaporator where heat is gained from re-evaporator. 


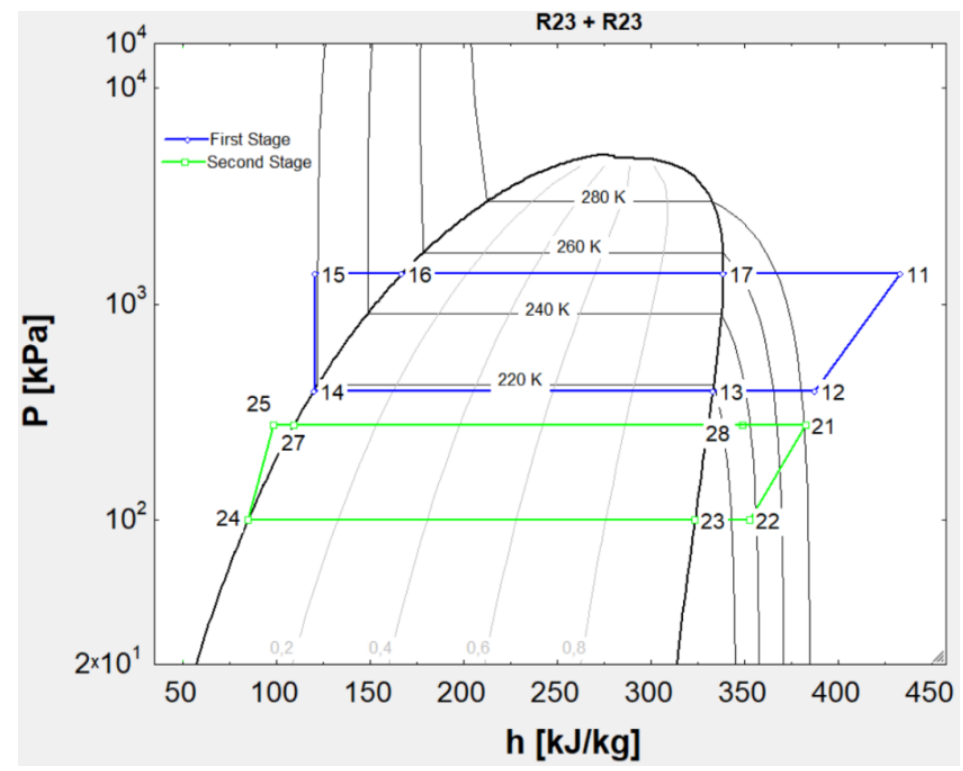

Figure 2. Pressure/enthalpy chart of double-stage Rankine cycle with R23 at each stage

\subsubsection{Organic Refrigerants}

Good working fluid should have a low steam and low liquid specific volume [17]. The specific volume of the fluid pressure in the condenser should be as small as possible to minimize the required feed pump work [16]. Table 2 shows physical, safety and environmental data of the working fluids used in the analyses.

Table 2. Physical, safety and environmental data of the working fluids

\begin{tabular}{|c|c|c|c|c|c|c|c|c|}
\hline Substance & $\begin{array}{c}\text { Molecular } \\
\text { mass } \\
(\mathbf{k g} / \mathbf{k m o l})\end{array}$ & $\mathbf{T}_{\mathbf{b p}}\left({ }^{\circ} \mathbf{C}\right)$ & $\begin{array}{c}\mathbf{T}_{\mathbf{c r}} \\
\left({ }^{\circ} \mathbf{C}\right)\end{array}$ & $\begin{array}{c}\mathbf{P}_{\text {cr }} \\
(\mathbf{M P a})\end{array}$ & $\begin{array}{c}\text { ASHRAE } \\
\mathbf{3 4} \text { safety } \\
\text { group }\end{array}$ & $\begin{array}{c}\text { Atmospheric } \\
\text { life time (yr) }\end{array}$ & ODP & $\begin{array}{c}\mathbf{G W P} \\
(\mathbf{1 0 0} \mathbf{~ y r})\end{array}$ \\
\hline $\mathrm{R} 134 \mathrm{a}$ & 102.03 & -26.1 & 101.1 & 4.06 & $\mathrm{~A} 1$ & 13.4 & 0 & 1370 \\
\hline $\mathrm{R} 410 \mathrm{a}$ & 72.58 & -51.4 & 71.4 & 4.90 & $\mathrm{~A} 1$ & - & 0 & 2100 \\
\hline $\mathrm{R} 3318$ & 200.03 & -6.0 & 115.2 & 2.778 & $\mathrm{~A} 1$ & 3200 & 0 & 10250 \\
\hline $\mathrm{R} 407 \mathrm{C}$ & 86.20 & -43.6 & 86.8 & 4.597 & $\mathrm{~A} 1$ & $\mathrm{n}$ & 0 & 1800 \\
\hline $\mathrm{R} 22$ & 86.47 & -40.8 & 96.1 & 4.99 & $\mathrm{~A} 1$ & 11.9 & 0.040 & 1790 \\
\hline $\mathrm{R} 23$ & 70.01 & -82.0 & 26.1 & 4.83 & $\mathrm{~A} 1$ & 222 & 0 & 14200 \\
\hline $\mathrm{R} 116$ & 138.01 & -78.1 & 19.9 & 3.05 & $\mathrm{~A} 1$ & 10000 & 0 & 12200 \\
\hline $\mathrm{R} 218$ & 188.02 & -36.8 & 71.9 & 2.64 & $\mathrm{~A} 1$ & 2600 & 0 & 8830 \\
\hline
\end{tabular}

$\mathrm{T}_{\mathrm{bp}}$ : Normal boiling point; $\mathrm{T}_{\mathrm{cr}}$ : Critical temperature; $\mathrm{P}_{\mathrm{cr}}$ : Critical pressure; ODP: Ozone depletion potential, relative to R-11; GWP: Global warming potential, relative to $\mathrm{CO}_{2}$. n.a: non available.

\subsubsection{Thermodynamic Analysis}

Rankine cycles with four components (pump, boiler, turbine and condenser) are constant-flow devices and therefore, all arithmetic operations constituting the Rankine cycle can be analyzed as the fixed-flow process. Kinetic and potential energy, work, and is small compared to the heat transfer terms are often ignored [18].

It is assumed that the pump and turbine are isentropic. The boiler and condenser do not require any work. Then the conservation of energy relationship for each device can be expressed as: 


\section{Stage -I Processes:}

Process $11-12$ is the actual expansion process in the Turbine-I.

$\dot{\mathrm{W}}_{\mathrm{T}-\mathrm{I}}=\dot{\mathrm{m}}_{\mathrm{I}} \times\left(\mathrm{h}_{11}-\mathrm{h}_{12}\right) \times \mathrm{n}_{\mathrm{m}}$

The isentropic efficiency of Turbine- $\mathrm{I}$ is $\mathrm{\eta}_{\mathrm{T}-\mathrm{I}}=0.8$ at the designed condition.

Process $12-13$ is the desuperheated process with Re-evaporator.

$\dot{\mathrm{Q}}_{\mathrm{r}}=\dot{\mathrm{m}}_{\mathrm{I}} \times\left(\mathrm{h}_{12}-\mathrm{h}_{13}\right)$

Process $13-14$ is the condensation process.

$\dot{\mathrm{Q}}_{\text {out-I }}=\dot{\mathrm{m}}_{\mathrm{I}} \times\left(\mathrm{h}_{13}-\mathrm{h}_{14}\right)$

Process $14-15$ is the pumping process.

$\dot{\mathrm{W}}_{\mathrm{p}-\mathrm{I}}=\dot{\mathrm{m}}_{\mathrm{I}} \times\left(\mathrm{h}_{14}-\mathrm{h}_{15}\right) \times \mathrm{y}_{\mathrm{p}}$

The pump efficiency is $\eta_{\mathrm{p}-\mathrm{I}}=0.8$ at the designed condition.

Process $15-11$ is the heating process by a solar collector.

$\dot{\mathrm{Q}}_{\mathrm{in}}=\dot{\mathrm{m}}_{\mathrm{I}} \times\left(\mathrm{h}_{11}-\mathrm{h}_{15}\right)$

\section{Stage-II Processes:}

Process $21-22$ is the actual expansion process in the Turbine-II.

$\dot{\mathrm{W}}_{\mathrm{T}-\mathrm{II}}=\dot{\mathrm{m}}_{\mathrm{II}} \times\left(\mathrm{h}_{21}-\mathrm{h}_{22}\right) \times \mathrm{y}_{\mathrm{T}-\mathrm{II}}$

The isentropic efficiency of an expander is $\mathrm{n}_{\mathrm{T}}$ ${ }_{2}=0.8$ at the designed condition.

Process $22-23$ is the Regenerator process.

$\dot{\mathrm{Q}}_{\mathrm{R}-2}=\dot{\mathrm{m}}_{\mathrm{II}} \times\left(\mathrm{h}_{22}-\mathrm{h}_{23}\right)$
When the heat source temperature is relatively high, the ORC with a regenerator is better than the basic ORC [19].

Process $23-24$ is the condensation process.

$\dot{\mathrm{Q}}_{\text {out }-2}=\dot{\mathrm{m}}_{\mathrm{II}} \times\left(\mathrm{h}_{23}-\mathrm{h}_{24}\right)$

Process $24-25$ is the pumping process.

$\dot{\mathrm{W}}_{\mathrm{p}-\mathrm{II}}=\dot{\mathrm{m}}_{\mathrm{II}} \times\left(\mathrm{h}_{24}-\mathrm{h}_{25}\right) \times \mathrm{\eta}_{\mathrm{p}-\mathrm{II}}$

The pump efficiency is $\eta_{\mathrm{p}-\mathrm{II}}=0.8$ at the designed condition.

Process $25-21$ is the heating process by $\mathrm{Re}$ evaporator.

$\dot{\mathrm{Q}}_{\mathrm{in}-\mathrm{II}}=\dot{\mathrm{m}}_{\mathrm{II}} \times\left(\mathrm{h}_{21}-\mathrm{h}_{25}\right)$

The net electrical power produced by the system is calculated from equation (11).

$\dot{\mathrm{W}}_{\mathrm{net}}=\left(\dot{\mathrm{W}}_{\mathrm{T}-\mathrm{I}}+\dot{\mathrm{W}}_{\mathrm{T}-\mathrm{II}}\right)-\left(\dot{\mathrm{W}}_{\mathrm{p}-\mathrm{I}}+\dot{\mathrm{W}}_{\mathrm{p}-\mathrm{II}}\right)$

The thermal efficiency of the double stage ORC system is determined from equation (12):

$\eta_{\mathrm{th}}=\frac{\dot{\mathrm{W}}_{\mathrm{net}}}{\dot{\mathrm{Q}}_{\mathrm{in}}}$

\section{The effectiveness - NTU Method:}

The effectiveness - NTU method was found in Kays and London in 1955. This method greatly simplified heat exchanger analysis [20]. All heat exchangers are calculated by the $\varepsilon$-NTU:

$\varepsilon=\frac{\dot{\mathrm{Q}}_{\mathrm{act}}}{\dot{\mathrm{Q}}_{\max }}$

$\varepsilon$ is the heat transfer effectiveness which is a dimensionless parameter. Defined as; the ratio of actual heat transfer rate to maximum possible heat transfer rate. 
To determine the maximum possible heat transfer rate in a heat exchanger, maximum temperature difference in a heat exchanger is the difference between the inlet temperature of the hot and cold fluids [19].

$\dot{\mathrm{Q}}_{\mathrm{act}}=\mathrm{C}_{\mathrm{h}}\left(\mathrm{T}_{\mathrm{h} \text {-in }}-\mathrm{T}_{\mathrm{h} \text {-out }}\right)=\mathrm{C}_{\mathrm{c}}\left(\mathrm{T}_{\mathrm{c} \text {-out }}-\mathrm{T}_{\mathrm{c} \text {-in }}\right)$

$\mathrm{C}_{\mathrm{h}}$ and $\mathrm{C}_{\mathrm{c}}$ are the heat capacity of the hot and cold fluids, respectively.

$\dot{\mathrm{Q}}_{\max }=\mathrm{C}_{\min }\left(\mathrm{T}_{\mathrm{h}-\text { in }}-\mathrm{T}_{\mathrm{c}-\text { in }}\right)$

The $\mathrm{C}_{\min }$ is the smaller fluid thermal capacity. The $\mathrm{U}$ is the overall heat transfer coefficient.

$\mathrm{NTU}=\frac{\mathrm{U} \times \mathrm{A}}{\mathrm{C}_{\min }}$

NTU is a dimensionless number which means number of transfer unit.

\section{RESULT AND DISCUSSIONS}

Thermodynamic properties of the R23 refrigerant in the first and second stages were determined with the EES (Engineering Equation Solver) software program. EES simplifies the process and is the assurance that the solver will operate at optimum efficiency. EES automatically identifies and groups equations that need to be solved and uses equations instead of assignments normally used in formal programming languages [21].

The effect on the system in the same situation is calculated by changing the refrigerant pair and turbine inlet temperature $\left(\mathrm{T}_{11}\right)$.

For Turbine Inlet Temperature is $355 \mathrm{~K}$ : Table 3 is obtained by using an engineering equation solver (EES). The thermodynamic values of the stage-I using R23 fluid when the first turbine inlet temperature $\left(T_{11}\right)$ is $355 \mathrm{~K}$.

Table 4 shows the thermodynamic values of the stage-II using R23 fluid when the first turbine inlet temperature $\left(T_{11}\right)$ is $355 \mathrm{~K}$.

Table 3. Thermodynamic properties of R23 in the stage-I

\begin{tabular}{|c|l|c|c|c|c|}
\hline Point & State & $\begin{array}{c}\text { Temperature } \\
(\mathbf{K})\end{array}$ & $\begin{array}{c}\text { Pressure } \\
(\mathbf{k P a})\end{array}$ & $\begin{array}{c}\text { Enthalpy } \\
(\mathbf{k J} / \mathbf{k g})\end{array}$ & $\begin{array}{c}\text { Entropy } \\
(\mathbf{k J}-\mathbf{k g} / \mathbf{K})\end{array}$ \\
\hline 11 & Superheated vapor & 355 & 1380 & 433.2 & 1.874 \\
\hline 12 & Superheated vapor (Scroll Expander) & 289.6 & 397.6 & 387.8 & 1.874 \\
\hline 13 & Superheated vapor & 218.7 & 397.6 & 333.2 & 1.658 \\
\hline 14 & Saturated liquid & 218.7 & 397.6 & 120 & 0.6825 \\
\hline 15 & Sub-cooled liquid (Pump) & 219.1 & 1380 & 120.8 & 0.6825 \\
\hline 16 & Saturated liquid & 252.7 & 1380 & 167.1 & 0.8789 \\
\hline 17 & Saturated vapor & 252.7 & 1380 & 338.8 & 1.558 \\
\hline
\end{tabular}

Table 4. Thermodynamic properties of R23 in the stage-II

\begin{tabular}{|c|l|c|c|c|c|}
\hline Point & State & $\begin{array}{c}\text { Temperature } \\
(\mathbf{K})\end{array}$ & $\begin{array}{c}\text { Pressure } \\
(\mathbf{k P a})\end{array}$ & $\begin{array}{c}\text { Enthalpy } \\
(\mathbf{k J / k g})\end{array}$ & $\begin{array}{c}\text { Entropy } \\
(\mathbf{k J}-\mathbf{k g} / \mathbf{K})\end{array}$ \\
\hline 21 & Superheated vapor & 281.4 & 275 & 383 & 1.9 \\
\hline 22 & Superheated vapor (Scroll Expander) & 234.5 & 100 & 352.7 & 1.9 \\
\hline 23 & Superheated vapor & 190.9 & 100 & 323.7 & 1.763 \\
\hline 24 & Saturated liquid & 190.9 & 100 & 84.91 & 0.5118 \\
\hline 25 & Sub-cooled liquid (Pump) & 191 & 275 & 98.17 & 0.5118 \\
\hline 26 & Saturated liquid & 210.4 & 275 & 109.4 & 0.6331 \\
\hline 27 & Saturated vapor & 210.4 & 275 & 330.7 & 1.686 \\
\hline
\end{tabular}


Table 5 shows the power output and thermal efficiency values of different fluid pairs when the first turbine inlet temperature $\left(T_{11}\right)$ is $355 \mathrm{~K}$. According to the results obtained, the highest power output was seen in the R23+R23 pair as $18.84 \mathrm{~kW}$ and the highest thermal efficiency was obtained in the RC318+RC318 pair as 6.708 .
For Turbine Inlet Temperature is 425K: The thermodynamic values of the stage-I using R23 fluid when the first turbine inlet temperature $\left(\mathrm{T}_{11}\right)$ is $425 \mathrm{~K}$ are given in Table 6

Table 7 represents the thermodynamic values of the stage-II using R23 fluid when the first turbine inlet temperature $\left(\mathrm{T}_{11}\right)$ is $425 \mathrm{~K}$.

Table 5. System performance for different refrigerant pairs at $355 \mathrm{~K}$

\begin{tabular}{|c|c|c|c|}
\hline Working fluids & $\begin{array}{c}\text { Turbine inlet } \\
\text { temperature (K) }\end{array}$ & Power output (kW) & $\begin{array}{c}\text { Thermal efficiency } \\
(\%)\end{array}$ \\
\hline $\mathrm{R} 134 \mathrm{a}+\mathrm{R} 134 \mathrm{a}$ & 355 & 14.31 & 6.251 \\
\hline $\mathrm{R} 410 \mathrm{a}+\mathrm{R} 410 \mathrm{a}$ & 355 & 18.57 & 6.165 \\
\hline RC318 + RC318 & 355 & 8.097 & 6.708 \\
\hline $\mathrm{R} 407 \mathrm{C}+\mathrm{R} 407 \mathrm{C}$ & 355 & 16.24 & 6.057 \\
\hline $\mathrm{R} 22+\mathrm{R} 22$ & 355 & 15.23 & 6.235 \\
\hline $\mathbf{R 2 3}+\mathbf{R 2 3}$ & 355 & 18.84 & 6.484 \\
\hline R116 + R116 & 355 & 11.47 & 6.192 \\
\hline R218 + R218 & 355 & 8.64 & 6.083 \\
\hline
\end{tabular}

Table 6. Thermodynamic properties of R23 in the stage-I

\begin{tabular}{|c|c|c|c|c|c|}
\hline Point & State & $\begin{array}{c}\text { Temperature } \\
(\mathbf{K})\end{array}$ & $\begin{array}{c}\text { Pressure } \\
(\mathbf{k P a})\end{array}$ & $\begin{array}{c}\text { Enthalpy } \\
(\mathbf{k J} / \mathbf{k g})\end{array}$ & $\begin{array}{c}\text { Entropy } \\
(\mathbf{k J}-\mathbf{k g} / \mathbf{K})\end{array}$ \\
\hline 11 & Superheated vapor & 425 & 1380 & 496.4 & 2.037 \\
\hline 12 & $\begin{array}{c}\text { Superheated vapor } \\
\text { (Scroll Expander) }\end{array}$ & 355.6 & 397.6 & 440.1 & 2.037 \\
\hline 13 & Superheated vapor & 218.7 & 397.6 & 333.2 & 1.658 \\
\hline 14 & Saturated liquid & 218.7 & 397.6 & 120 & 0.6825 \\
\hline 15 & $\begin{array}{c}\text { Sub-cooled liquid } \\
\text { (Pump) }\end{array}$ & 219.1 & 1380 & 120.8 & 0.6825 \\
\hline 16 & Saturated liquid & 252.7 & 1380 & 167.1 & 0.8789 \\
\hline 17 & Saturated vapor & 252.7 & 1380 & 338.8 & 1.558 \\
\hline
\end{tabular}

Table 7. Thermodynamic properties of R23 in the stage-II

\begin{tabular}{|c|l|c|c|c|c|}
\hline Point & \multicolumn{1}{|c|}{ State } & $\begin{array}{c}\text { Temperature } \\
(\mathbf{K})\end{array}$ & $\begin{array}{c}\text { Pressure } \\
(\mathbf{k P a})\end{array}$ & $\begin{array}{c}\text { Enthalpy } \\
(\mathbf{k J} / \mathbf{k g})\end{array}$ & $\begin{array}{c}\text { Entropy } \\
(\mathbf{k J}-\mathbf{k g} / \mathbf{K})\end{array}$ \\
\hline 21 & Superheated vapor & 347.3 & 275 & 434.1 & 2.063 \\
\hline 22 & $\begin{array}{l}\text { Superheated vapor } \\
\text { (Scroll Expander) }\end{array}$ & 296.3 & 100 & 395.8 & 2.063 \\
\hline 23 & Superheated vapor & 190.9 & 100 & 323.7 & 1.763 \\
\hline 24 & Saturated liquid & 190.9 & 100 & 84.91 & 0.5118 \\
\hline 25 & $\begin{array}{l}\text { Sub-cooled liquid } \\
\text { (Pump) }\end{array}$ & 191 & 275 & 101.5 & 0.5118 \\
\hline 26 & Saturated liquid & 210.4 & 275 & 109.4 & 1.939 \\
\hline 27 & Saturated vapor & 210.4 & 275 & 330.7 & 1.686 \\
\hline
\end{tabular}


Table 8 shows the power output and thermal efficiency values of different fluid pairs when the first turbine inlet temperature $\left(\mathrm{T}_{11}\right)$ is $425 \mathrm{~K}$. According to the results obtained, the system's highest power output and thermal efficiency values were obtained when using $\mathrm{R} 23+\mathrm{R} 23$ pair as the value of $23.82 \mathrm{~kW}$ and 6.818 , respectively. This means as seen from table $8, \mathrm{R} 23+\mathrm{R} 23$ pair gives the highest power output and thermal efficiency when the input temperature of the turbine-I rises

Table 8. System performance for different refrigerant pairs at $425 \mathrm{~K}$

\begin{tabular}{|l|c|c|c|}
\hline Working fluids & $\begin{array}{c}\text { Turbine inlet } \\
\text { temperature (K) }\end{array}$ & Power output $(\mathbf{k W})$ & $\begin{array}{c}\text { Thermal } \\
\text { efficiency }(\boldsymbol{\%})\end{array}$ \\
\hline R134a + R134a & 425 & 18.16 & 6.049 \\
\hline R410a + R410a & 425 & 23.63 & 6.418 \\
\hline RC318+ RC318 & 425 & 9.994 & 5.338 \\
\hline R407C + R407C & 425 & 20.65 & 6.13 \\
\hline R22+ R22 & 425 & 19.44 & 6.524 \\
\hline R23 + R23 & 425 & $\mathbf{2 3 . 8 2}$ & $\mathbf{6 . 8 1 8}$ \\
\hline R116+ R116 & 425 & 14.07 & 5.736 \\
\hline R218+ R218 & 425 & 10.64 & 5.176 \\
\hline
\end{tabular}

Figure 3 indicates power output values at $355 \mathrm{~K}$, $390 \mathrm{~K}$ and $425 \mathrm{~K}$ turbine inlet temperature $\left(\mathrm{T}_{11}\right)$ values for each refrigerant pair. It is observed that the RC318 + RC318 pair gives the lower power output at each temperature value. On the other hand, the R23 + R23 pair gives the higher power output at each temperature. The lowest power output was obtained as $8.097 \mathrm{~kW}$ at $355 \mathrm{~K}$ turbine inlet temperature $\left(T_{11}\right)$ when using the R318 pair, and the highest value determined as $23.82 \mathrm{~kW}$ at $425 \mathrm{~K}$ when using the R23 pair.

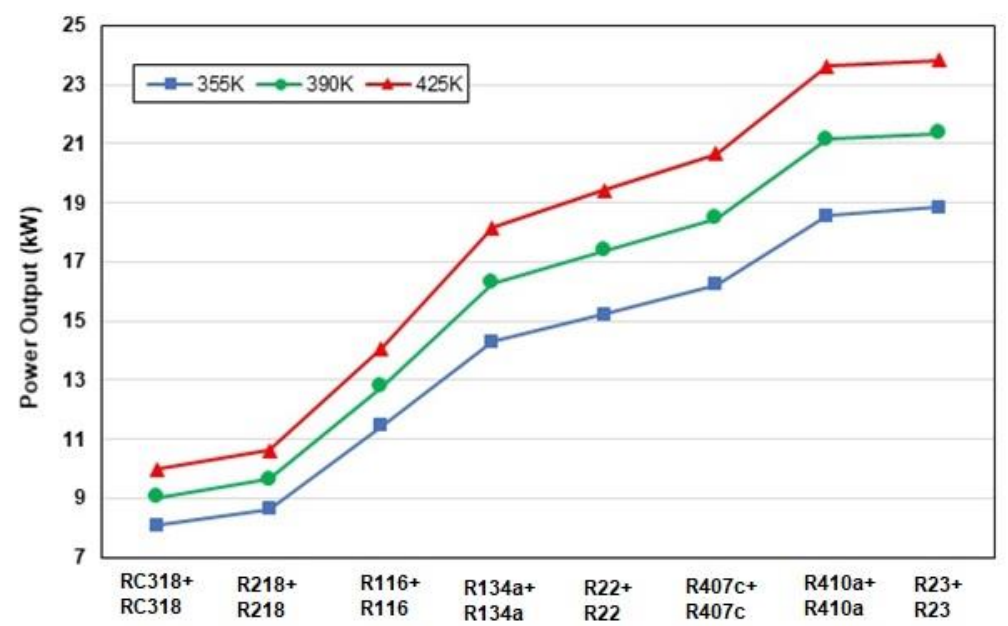

Figure 3. Power outputs when using different working fluid pairs at different temperatures

The relationship between refrigerant pairs for each temperature is presented in Figure 4. Increasing the turbine's inlet temperature has a negative impact on the thermal efficiency of the RC $318+\mathrm{RC} 318$ pair. That thermal efficiency dramatically decreases from 6.708 to 5.338 . It is observed that the thermal efficiency of R22, R407c, R410a and R23 increases as the temperature increases. On the other hand, in other refrigerants, the thermal efficiencies decreased as the temperature increased. 


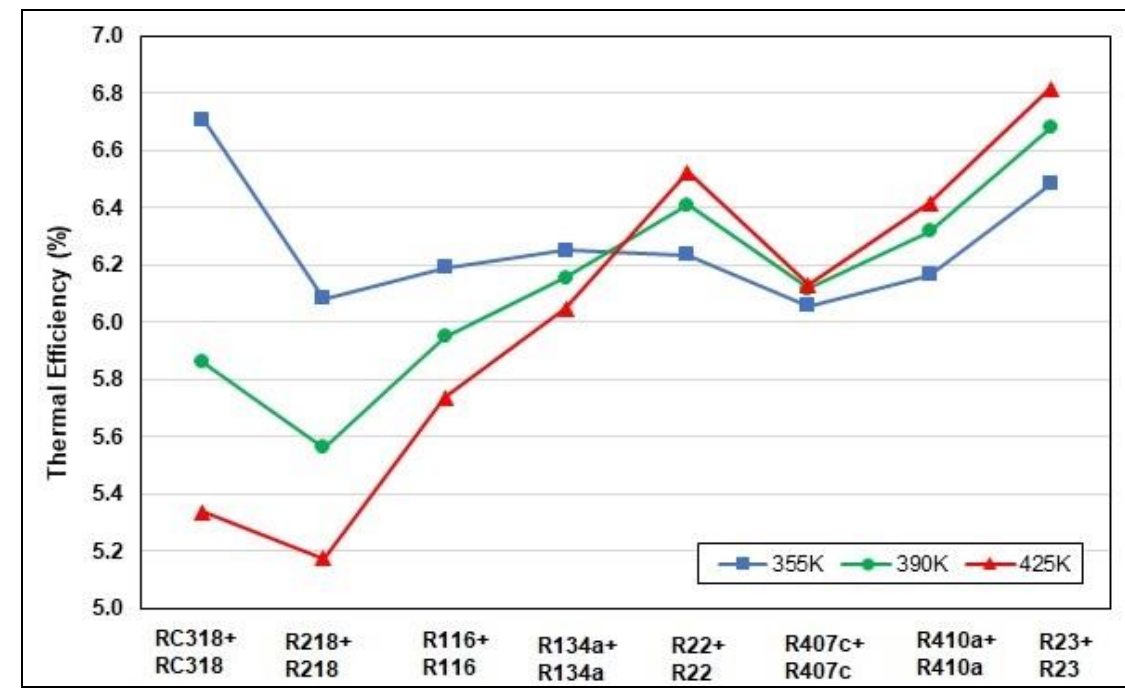

Figure 4. The system's thermal efficiency value for different working fluid pairs at the $355 \mathrm{~K}, 390 \mathrm{~K}$ and $425 \mathrm{~K}$

Figure 5 shows power output from 8 different fluid pairs according to the turbine inlet temperature. It has been observed that the R410a + R410a pair gives about the same power output as the R23 + R23 pair, with a difference of about one percent at all temperatures. And between all of the pairs, the RC318+RC318 pair gave the smallest net power output for each turbine inlet temperature $\left(\mathrm{T}_{11}\right)$ value.

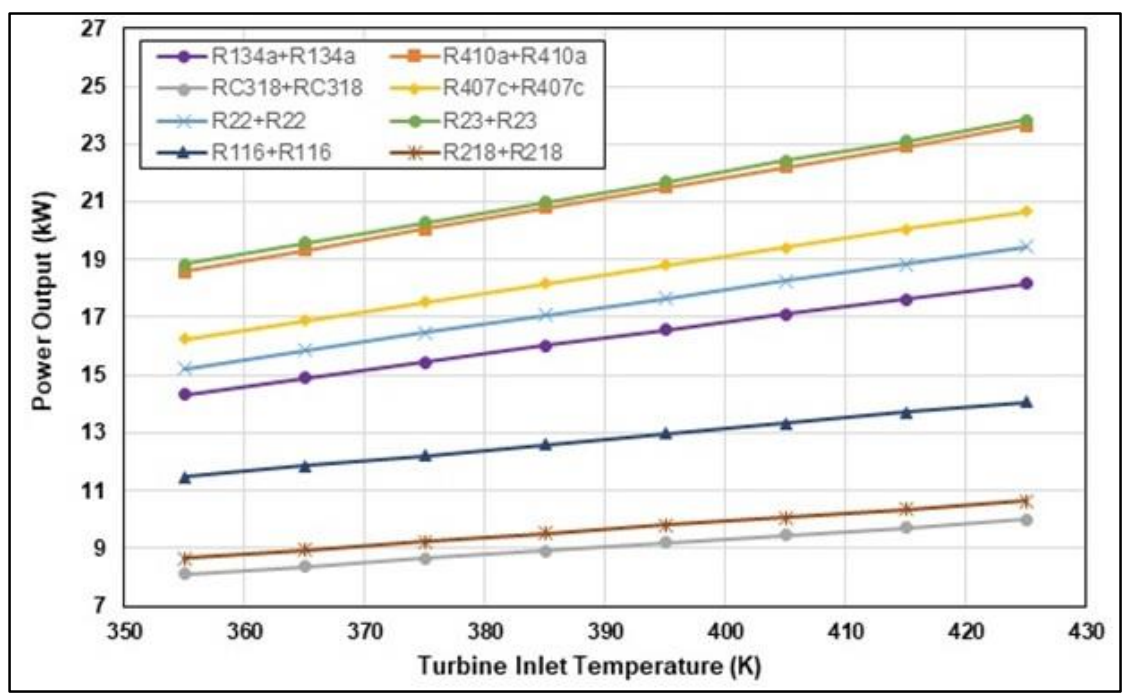

Figure 5. System net power output according to different pairs and temperatures

Figure 6 presents thermal efficiency of the system versus turbine inlet temperature for R134a+R134a, R410a+R410a， RC318+RC318， R407c+R407c,
R22+R22, R23+R23, R116+R116 and R218+R218 refrigerant pairs. It is seen that when the $\mathrm{R} 23+\mathrm{R} 23$ pair is used and turbine inlet temperature is $425 \mathrm{~K}$ 
in the ORC system, the thermal efficiency is $4.31 \%$ greater than the $\mathrm{R} 22+\mathrm{R} 22$ pair. The system's thermal efficiency increases with temperature when R23+R23, R22+R22, $\mathrm{R} 410 \mathrm{a}+\mathrm{R} 410 \mathrm{a}$ and $\mathrm{R} 407 \mathrm{c}+\mathrm{R} 407 \mathrm{c}$ refrigerant pairs use. The thermal efficiency of other pairs decreases when the temperature is increased. On the other hand, when R218+R218 pair is used, the smallest system thermal efficiency value among the other pairs was obtained at all temperatures.

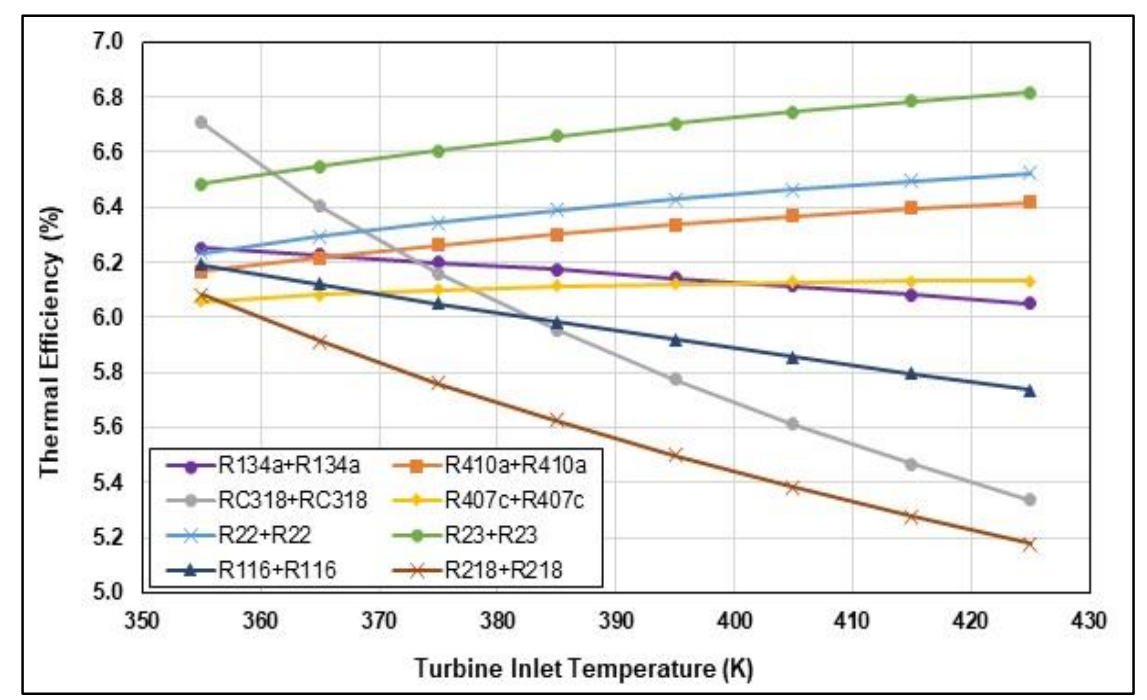

Figure 6. Thermal efficiency of the system versus turbine inlet temperature for different refrigerant pairs

\section{CONCLUSION}

In this study double stage organic Rankine cycle (ORC) which is heated with the solar collector is solved with the EES program. The results can be summarized as follows:

- Different solar collector temperatures are considered in the present analysis, the highest thermal efficiency and power output are achieved at $425 \mathrm{~K}$.

- The thermal efficiency values of the system at $325 \mathrm{~K}$ turbine inlet temperature are observed as the highest value for the RC318 + RC318 pair. But that thermal efficiency value dramatically decreases when the solar collector temperature is increased.

- Among all refrigerants, R23 can be recommended for all working temperatures. Because R23 + R23 pair gives the highest net power output and thermal efficiency values for all temperatures and working fluids.

- As the turbine inlet temperature increases, the net power output of the system increases for all refrigerant pairs, but the system's thermal efficiency against turbine inlet temperature increases only when R23, R22, R410a and $\mathrm{R} 407 \mathrm{c}$ refrigerant pairs are used.

\section{REFERENCES}

1. Obafunmi, Jaiyejeje S., 2014. Thermodynamic Analysis of Organic Rankine Cycles. Eastern Mediterranean University Gazimağusa, North Cyprus.

2. Quoilin, S., Orsz, M., Hemond., Lemort, V., 2011. Performance and Design Optimization of a Low-cost Solar Organic Rankine Cycle for Remote Power Generation. Solar Energy 85, 955-966.

3. Becquin, G., Lehar, M., 2012. Two Algorithms for Reliable Estimation of Organic Rankine 
Performance. J. Eng. Gas Turbines Power, 134(4), 044504. DOI:10.1115/1.4004839.

4. Wali, E., 2980. Optimum Working Fluids for Solar Powered Rankine Cycle Cooling of Buildings. Solar Energy, 25(3), 235-241.

5. Davidson, T.A., 1977. Design and Analysis of a $1 \mathrm{~kW}$ Rankine Power Cycle, Employing a Multi-vane Expander, for Use with a Low Temperature Solar Collector. Master's Thesis, Massachusetts Institute of Technology, Cambridge, MA, USA.

6. Chen, H., Goswami, D.Y., Stefanakos, E.K., 2010. A Review of Thermodynamic Cycles and Working Fluids for the Conversion of Low-grade Heat. Renew Sustain Energy Rev., 14(9), 3059-3067.

7. http://www.clean-energy-ideas.com/ geothermal_power.html,

8. Lee, D.H., 2014. Organic Rankine Cycle Power Generator. $8^{\text {th }}$ Fluid Machinery Core Technology Lecture of Korea Society for Fluid Machinery, 169-179.

9. Eyidogan, M., Kilic, F.C., Kaya, D., Coban, V., Cagman, S., 2016. Investigation of Organic Rankine Cycle (ORC) Technologies in Turkey from the Technical and Economic Point of View. Renewable and Sustainable Energy Reviews, 58(C), 885-895.

10.Lim, H.S., Choi, B.S., Park, M.R., Hwang, S.C., Park, J.Y., Seo, J., Bang, J.S., Kim, B.O., 2017. Performance Evaluation of Two-stage Turbine for the Organic Rankine Cycle System. Journal of Mechanical Science and Technology, 31(12), 5849-5855.

11. Wang, Q., Wang, J., Li, T., Meng, N., 2020. Techno-economic Performance of Two-stage Series Evaporation Organic Rankine Cycle with Dual-level Heat Sources. Applied Thermal Engineering, 171(8), 115078.

12. Bertrand, F.T., Papadakis, G., Lambrinos, G., Frangoudakis, A,. 2009. Fluid Selection for a Low Temperature Solar Organic Rankine Cycle. Applied Thermal Engineering, 29(1112), 2468-2476.

13. Tchanche, B.F., Papadakis, G., Lambrinos, G., Frangoudakis, A., 2008. Criteria for Working Fluids Selection in Low-temperature Solar Organic Rankine Cycles. in: Proc. Eurosun Conf., Lisbon, Portugal, 1-8.
14. Maizza, V., Maizza, A., 1996. Working Fluids in Non-steady Flows for Waste Energyrecovery Systems. Applied Thermal Energy, 16(7), 579-590.

15. Borsukiewcz, A., Nowak, W., 2007. Comparative Analysis of Natural and Synthetic Refrigerants in Application to Low Temperature Clausius-rankinecycle. Energy, 32, 344-352.

16. Bertrant, T.F., Papadakis, G., Lambrinos, G., Frangoudakis, A., 2008. Criteria for Working Fluids Selection in Low-temperature Solar Organic Rankine Cycles. $1^{\text {st }}$ International Congress on Heating. Cooling and Buildings, 1-8.

17. Badr, O., Probert, S.D., O'Callaghan, P.W., 1985. Selecting a Working Fluid for a Rankinecycle Engine. Applied Energy, 21, 1-42.

18. Cengel, Y.A., Boles, M.A., 2014. Thermodynamics: An Engineering Approach. $5^{\text {th }}$ Ed., McGraw-Hill Education, 554-555.

19. Li, X., Liu, T., Chen, L., 2018. Thermodynamic Performance Analysis of an Improved Two-stage Organic Rankine Cycle. School of Mechanical Engineering, Tianjin Polytechnic University, Tianjin 300387, China.

20. Cengel, Y.A., Heat Transfer: A Practical Approach. $2^{\text {th }}$ Ed., 690-694.

21. Klein, S.A., 2003. Engineering Equation Solver -Manual. F-Chart Software, Box.

\begin{tabular}{|c|c|c|c|}
\hline \multicolumn{4}{|c|}{ Nomenclature } \\
\hline $\mathrm{h}$ & \multicolumn{3}{|c|}{ Enthalpy $\left[\mathrm{kjkg}^{-1}\right]$} \\
\hline$\dot{m}$ & \multicolumn{3}{|c|}{ mass flow rate $\left[\mathrm{kgs}^{-1}\right]$} \\
\hline$\dot{Q}$ & \multicolumn{3}{|c|}{ heat transfer rate $[\mathrm{kW}]$} \\
\hline$C$ & \multicolumn{3}{|c|}{ heat capacity rate $\left[\mathrm{kW}^{\circ} \mathrm{C}^{-1}\right]$} \\
\hline$T$ & \multicolumn{3}{|c|}{ temperature $\left[{ }^{\circ} \mathrm{C}\right.$ or $\left.\mathrm{K}\right]$} \\
\hline$\dot{W}$ & \multicolumn{3}{|c|}{ work $[\mathrm{kW}]$} \\
\hline $\mathrm{A}$ & \multicolumn{3}{|c|}{ surface area $\left[\mathrm{m}^{2}\right]$} \\
\hline \multicolumn{4}{|c|}{ Greek Letter } \\
\hline$\eta$ & \multicolumn{3}{|l|}{ efficiency } \\
\hline \multicolumn{4}{|c|}{ Subscripts } \\
\hline I & upper stage & th & thermal \\
\hline II & lower Stage & $\min$ & minimum \\
\hline $\mathrm{p}$ & pump & $\max$ & maximum \\
\hline out & outgoing & act & actual \\
\hline in & incoming & $\mathrm{m}$ & mechanic \\
\hline $\mathrm{r}$ & re-evaporator & $\mathrm{h}$ & hot \\
\hline $\mathrm{T}$ & turbine & $\mathrm{c}$ & cold \\
\hline
\end{tabular}


